\title{
Differential expression of genes for aromatase and estrogen receptor during the gonadal development in chicken embryos
}

\author{
O Nakabayashi ${ }^{1,2}$, H Kikuchi $^{2}$, T Kikuchi ${ }^{2}$ and S Mizuno ${ }^{1}$ \\ ${ }^{1}$ Laboratory of Molecular Biology, Department of Applied Biological Chemistry, Faculty of Agriculture, \\ Tohoku University, 1-1 Tsutsumidori-Amamiyamachi, Aoba-ku, Sendai 981, Japan \\ ${ }^{2}$ Department of Animal Models for Human Disease, National Institute of Neuroscience, NCNP, Kodaira, \\ Tokyo 187, Japan
}

(Requests for offprints should be addressed to S Mizuno)

\begin{abstract}
In birds, differentiation of embryonic gonads is not as strictly determined by the genetic sex as it is in mammals, and can be influenced by early manipulation with a sex steroid hormone. Thus administration of an aromatase inhibitor induces testis development in the genetic female, and administration of estrogen induces a left ovotestis in the genetic male embryo. Another feature of avian gonadogenesis is that only the left ovary develops in most species. Molecular mechanisms underlying these features at the level of gene expression have not been elucidated. In this paper, we present evidence that a gene for aromatase cytochrome $\mathrm{P}-450$, an enzyme required for the last step in the synthesis of estradiol-17 $\beta$, is expressed in medullae of the left and right gonads of a female chicken embryo, but not in those of a male chicken embryo,
\end{abstract}

and that an estrogen receptor gene is expressed only in epithelium (and cortex later, in the female) of the left, not the right, gonad of both sexes, but the expression in the male left gonad is temporary and restricted to an early stage of development. Differential expression of these two genes serves well to explain the above features of gonadal development in birds. Furthermore, in ovo administration of estradiol-17 $\beta$ from the 5 th to the 14 th day of incubation does not cause expression of the estrogen receptor gene in the right gonad of chicken embryos of either sex, suggesting that the absence of expression of the estrogen receptor gene in the right gonad is not the result of down-regulation, but may be regarded as an important cause of the unilateral ovarian development.

Fournal of Molecular Endocrinology (1998) 20, 193-202

\section{INTRODUCTION}

Sex chromosomes of birds are female heterogametic; $Z Z$ for male and $Z W$ for female. The observations that the left ovotestis and the right testis are developed at hatching in an individual chicken having $3 \mathrm{~A}+\mathrm{ZZW}$ triploid genome (Ohno et al. 1963, Lin et al. 1995) suggest that the W chromosome may contain a gene that triggers the development of a left ovary, but that its determinant role is not as strict as that of the sry (or $S R Y$ ) gene on the mammalian Y chromosome, which has a key role leading to the development of testis (Koopman et al. 1991). However, such a gene on the $W$ chromosome has yet to be identified.

The female sex differentiation of chickens is characterized by two biologically interesting features.
First, as mentioned above, the control of differentiation of the female gonad by gene(s) on the $\mathrm{W}$ chromosome does not seem to be decisive, because administration of an aromatase inhibitor to genetically female embryos before the 7 th day of incubation caused nearly all the hatched chickens to have male-type vent morphology. About $50 \%$ of the treated genetic females developed testes, although they were infertile (Elbrecht \& Smith 1992). Thus the in vivo exposure to estrogen at an early stage of embryonic development seems to be crucial for the normal differentiation of an ovary in chickens. Secondly, in female chickens, as in many other female birds, only the left gonad develops into a functional ovary (Romanoff 1960). In contrast, the right gonad gains its maximum weight at the 10 th to 12 th day of incubation ('Teng $\&$ Teng 1977), but does 


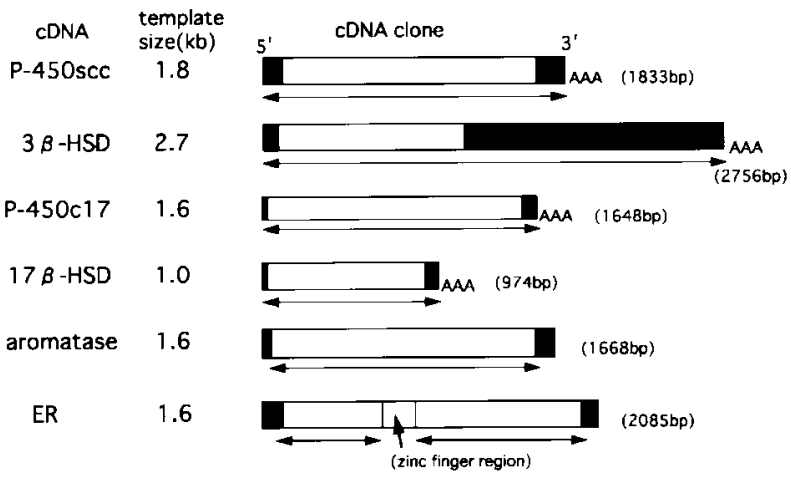

FIGURE 1. The chicken cDNA templates used for in vitro synthesis of antisense and sense RNA probes. The origins of cDNA clones are described in Materials and Methods. The size of each cDNA insert is given in parentheses. Untranslated region (filled box), coding region (open box), the cDNA region used as a template for in vitro RNA synthesis (double-headed arrow) and its total size are shown.

not form cortex and thereafter regresses rapidly and becomes a rudimentary tissue. Molecular mechanisims underlying these two features at the level of gene expression have not been elucidated.

In this study, we examined the existence of transcripts for the five genes required for conversion of cholesterol to estradiol-17 $\beta$ and a transcript of an estrogen receptor (ER) gene in left and right gonads of chicken embryos of both sexes, using in situ hybridization to tissue sections with antisense RNA probes and RT-PCR (reverse transcription followed by polymerase chain reaction) using templates and primers all derived from the cloned chicken cDNA sequences.

\section{MATERIALS AND METHODS}

\section{RNA probes}

The cDNA templates, all of chicken origin, used for in vitro synthesis of RNA probes are shown in Fig. 1. The cDNA sequences for cholesterol side-chain cleavage P-450 (P-450 scc) (Nomura et al. 1997), $3 \beta$-hydroxysteroid dehydrogenase $/ \Delta^{5-4}$ isomerase

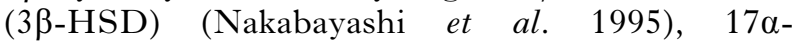
hydroxylase P-450 (P-450c17) (Ono et al. 1988) and $17 \beta$-hydroxysteroid dehydrogenase (17 $\beta$-HSD) were cloned in the laboratory of one of the authors. (The cloned $17 \beta-\mathrm{HSD}$ is a highly ovary-specific enzyme, presented by Wajima et al. (1995). Its cDNA sequence appears in the DDBJ, EMBL and GenBank nucleotide sequence databases with accession No. AB002410.) The cDNA sequences for aromatase cytochrome P-450 (aromatase) (McPhaul et al. 1988) and estrogen receptor (Krust et al. 1986) were generated by RT-PCR from the total RNA preparations of the ovarian small yellow follicles and the oviduct, respectively, using primers synthesized according to the published cDNA sequences. The aromatase cDNA sequence used was from nucleotide positions 80-1643 and the estrogen receptor cDNA sequence was 188-1987, but the region containing two zinc fingers (region C: 705-970) in the latter sequence was not included, in order to increase the specificity of the RNA probe. These cDNA sequences were cloned using the following vectors: pcDNAI (Invitrogen, San Diego, CA, USA) for P-450 scc, pBluescript SK (Stratagene, La Jolla, CA, USA) for $3 \beta-H S D, P-450 c 17$, aromatase and estrogen receptor, and pBluescript KS (Stratagene) for $17 \beta$-HSD. These recombinant plasmids were cleaved at a site in the polylinker region and transcribed in vitro to synthesize digoxigenin (DIG)labeled antisense or sense RNA probes as follows. A $20 \mu \mathrm{l}$ reaction mixture containing $1 \mu \mathrm{g}$ cDNA template, 40 units RNase inhibitor from human placenta (Toyobo, Osaka, Japan), 20 units SP6 (Boehringer Mannheim, Mannheim, Germany), T3 (Boehringer Mannheim) or T7 (Promega, Madison, WI, USA) RNA polymerase, $1 \mathrm{mM}$ each of ATP, GTP and CTP, $0.65 \mathrm{mM}$ UTP, $0.35 \mathrm{mM}$ DIG-11-UTP (Boehringer Mannheim), $40 \mathrm{mM}$ Tris- $\mathrm{HCl}$ (pH $8 \cdot 0), 8 \mathrm{mM} \mathrm{MgCl}_{2}, 2 \mathrm{mM}$ spermidine and $50 \mathrm{mM}$ $\mathrm{NaCl}$, was incubated at $37^{\circ} \mathrm{C}$ for $60 \mathrm{~min}$. The mixture was then treated with 50 units RNase-free DNase I (Boehringer Mannheim) in the presence of $20 \mu \mathrm{g}$ yeast tRNA and 40 units RNase inhibitor (Toyobo) at $37^{\circ} \mathrm{C}$ for $10 \mathrm{~min}$. RNA products were precipitated with ethanol and partially hydrolyzed in $40 \mathrm{mM} \mathrm{NaHCO}-60 \mathrm{mM} \mathrm{NaCO}$ to yield probes having mean fragment sizes of about 300 nucleotides.

\section{Incubation of eggs, in ovo treatment with estrogen and identification of the sex of embryos}

Fertilized eggs of White Leghorn chickens were incubated at $38{ }^{\circ} \mathrm{C}$. The sex of a 5-7-day embryo was determined by slot blot hybridization with the $\mathrm{W}$ chromosome-specific $0.7 \mathrm{~kb}$ XhoI-family probe (Kodama et al. 1987) to the DNA extracted from the extraembryonic membrane of an individual embryo (Mizuno et al. 1993). The sex of a later-stage embryo was determined from the morphology of gonads. When embryos were treated with estrogen, $25 \mu \mathrm{l}$ estradiol-17 $(0 \cdot 1 \mathrm{mg} / \mathrm{ml})$ in $70 \%$ ethanol or $25 \mu \mathrm{l}$ $70 \%$ ethanol as a control was injected into the air cell of an egg at the 5 th day of incubation and incubation was continued to the 14 th day. 


\section{In situ hybridization}

A block of tissue containing left and right gonads was excised from an individual embryo after 7-14 days of incubation, fixed in PBS $\left(7 \mathrm{mM} \mathrm{Na}_{2} \mathrm{HPO}_{4}\right.$, $3 \mathrm{mM} \mathrm{NaH} \mathrm{PO}_{4}, 130 \mathrm{mM} \mathrm{NaCl}$ ) containing $4 \%$ paraformaldehyde at $4{ }^{\circ} \mathrm{C}$ for $16 \mathrm{~h}$, dehydrated and embedded in paraffin using a standard procedure. Sections $8 \mu \mathrm{m}$ thick were cut in a transverse plane containing left and right gonads, and mounted on a silane-coated slide glass. After the paraffin was removed in xylene, the sections were washed in a series of reducing concentrations of ethanol (from 100 to $70 \%)$ and finally in Tris-EDTA $(10 \mathrm{mM}$ Tris-HCl pH 7.4, $1 \mathrm{mM}$ EDTA), before being treated with $10 \mu \mathrm{g} / \mathrm{ml}$ proteinase $\mathrm{K}$ in Tris-EDTA at $37^{\circ} \mathrm{C}$ for $20 \mathrm{~min}$, fixed again in PBS containing $4 \%$ paraformaldehyde, and washed successively in $0 \cdot 1 \mathrm{M}$ triethanolamine- $\mathrm{HCl}, \mathrm{pH} 8.0$ (TEA), $0 \cdot 1 \mathrm{M}$ TEA containing $0 \cdot 25 \%$ anhydrous acetic acid, 70 and $80 \%$ ethanol, and air-dried. Hybridization of an RNA probe was carried out in a reaction mixture (50 $\mu \mathrm{l} /$ slide) containing $50 \mathrm{ng}$ DIG-labeled RNA probe, $10 \mathrm{mM}$ Tris-HCl (pH 7·6), $1 \mathrm{mM}$ EDTA, $600 \mathrm{mM} \mathrm{NaCl}, 0 \cdot 25 \%$ SDS, $1 \times$ Denhardt's solution, $10 \%$ sodium dextran sulfate, $200 \mu \mathrm{g} / \mathrm{ml}$ yeast tRNA and $50 \%$ formamide, at $50{ }^{\circ} \mathrm{C}$ for $16 \mathrm{~h}$. After the reaction, the slide was washed in $2 \times \mathrm{SSC}$ containing $50 \%$ formamide at $60{ }^{\circ} \mathrm{C}$ for $30 \mathrm{~min}$, incubated in TNE $(10 \mathrm{mM}$ Tris- $\mathrm{HCl}, \mathrm{pH} 7 \cdot 4$, $1 \mathrm{mM}$ EDTA, $500 \mathrm{mM} \mathrm{NaCl}$ ) containing $1 \mu \mathrm{g} / \mathrm{ml}$ RNase A (Boehringer Mannheim) at $37^{\circ} \mathrm{C}$ for $30 \mathrm{~min}$, and washed successively in $2 \times \mathrm{SSC}$ at $50{ }^{\circ} \mathrm{C}$ for $20 \mathrm{~min}$ and in $0.2 \times \mathrm{SSC}$ at $50{ }^{\circ} \mathrm{C}$ for 20 min twice. Detection of hybrids was carried out at $25{ }^{\circ} \mathrm{C}$ as follows. The slide was first incubated in $4 \times \mathrm{SSC}$ containing $1.5 \%$ blocking reagent (Boehringer Mannheim) for $1 \mathrm{~h}$, then reacted with 500-fold diluted alkaline phosphataseconjugated sheep anti-DIG antibody (Boehringer Mannheim) in $4 \times \mathrm{SCC}$ for $1 \mathrm{~h}$ and washed in $4 \times \mathrm{SSC}$ containing $0.05 \%$ Tween 20 for $5 \mathrm{~min}$ three times. The slides that were reacted with antisense RNA probes for mRNAs of the five steroidogenic enzymes were color-developed with $450 \mu \mathrm{g} / \mathrm{ml}$ NBT (nitro blue tetrazolium) and $175 \mu \mathrm{g} / \mathrm{ml}$ 5-bromo-4-chloro-3-indoryl phosphate in $100 \mathrm{mM}$ Tris- $\mathrm{HCl}(\mathrm{pH} 9 \cdot 5), 100 \mathrm{mM} \mathrm{NaCl}$, $50 \mathrm{mM} \mathrm{MgCl}_{2}$ for $4 \mathrm{~h}$. The slide that was reacted with the antisense RNA probe for estrogen receptor mRNA was first incubated in $4 \times$ SSC containing 200-fold diluted alkaline phosphatase$\begin{array}{llll}\text { conjugated rabbit anti-sheep } & \operatorname{IgG} & \mathrm{F}\left(\mathrm{ab}^{\prime}\right)_{2}\end{array}$ (Rockland, Gilbertsville, PA, USA) at $25^{\circ} \mathrm{C}$ for $1 \mathrm{~h}$, followed by washing and color-development as above.

\section{RT-PCR}

Total RNA was prepared by the guanidinium thiocyanate/CsCl method (Sambrook et al. 1989) from a mixture of the left and right gonads of an individual embryo for the detection of $17 \beta$-HSD and aromatase mRNAs. Total RNA was prepared from an individual left or right gonad using the method of Lizardi \& Engelberg (1979) for the detection of estrogen receptor and glyceraldehyde3-phosphate dehydrogenase (GAPDH) mRNAs. One microgram of the RNA sample was subjected to the reverse transcriptase reaction in a $30 \mu \mathrm{l}$ mixture containing $50 \mathrm{mM}$ Tris- $\mathrm{HCl}(\mathrm{pH} 8 \cdot 3)$, $75 \mathrm{mM} \mathrm{KCl}, 3 \mathrm{mM} \mathrm{MgCl}_{2}, 100 \mathrm{mM}$ dithiothreitol, 15 units RNase inhibitor (TOYOBO), $100 \mathrm{nM}$ each dATP, dGTP, dTTP and dCTP, $200 \mathrm{ng}$ random hexamer (Pharmacia Biotech, Uppsala, Sweden) and 200 units M-MLV reverse transcriptase (Gibco BRL, Gaithersburg, MD, USA) at $42{ }^{\circ} \mathrm{C}$ for $1 \mathrm{~h}$. The total cDNA synthesized in one reaction was amplified by PCR, applying the numbers of cycles given in the figures (Figs 3 and 5) or their legends. One cycle consisted of $30 \mathrm{~s}$ at $95{ }^{\circ} \mathrm{C}$ for denaturation, $90 \mathrm{~s}$ at $60^{\circ} \mathrm{C}$ (for $17 \beta-H S D$ ) or $62{ }^{\circ} \mathrm{C}$ (for aromatase, estrogen receptor and GAPDH) for annealing, and $30 \mathrm{~s}$ at $72{ }^{\circ} \mathrm{C}$ for elongation. Sets of primers used were: 5'-GGCCATGAGAGCAGT GTTT-3' (forward, corresponding to nucleotide positions 342-360) and 5'-AGTACACGGCGTT GAAGGG-3' (reverse, corresponding to nucleotide positions 493-475) for 17 $\beta$-HSD; 5' CGACAAAA GCTTTCCACTGT-3' (forward, corresponding to nucleotide positions 883-902) and 5'-AGCAGCAA TCATCATCTCCA-3' (reverse, corresponding to nucleotide positions 1017-998) for aromatase; 5'-AT GATCGGCTTAGTCTGGCGCTC-3' (forward, corresponding to nucleotide positions 1346-1368) and 5'-GGTAGTACGCTGCTGGGTTT CTC-3' (reverse, corresponding to nucleotide positions 20222000) for estrogen receptor; 5 '-CACTATAAAGGC GAGATG-3' (forward, corresponding to nucleotide positions 15-32) and 5'-GGCTGTGTGCTT GGCTCA-3' (reverse, corresponding to nucleotide positions 1046-1029) for GAPDH (Dugaiczyk et al. 1983).

\section{RESULTS}

\section{Differential expression of $17 \beta-H S D$ and aromatase genes}

In chicken embryos, the morphological differentiation of the gonads starts at about the 6th day of incubation (Romanoff 1960). The presence of transcripts for the five enzymes (P-450 scc, 
$3 \beta$-HSD, P-450c17, $17 \beta-H S D$ and aromatase) required for the conversion of cholesterol to estradiol- $17 \beta$ was examined by in situ hybridization with DIG-labeled antisense RNA probes to tissue sections containing left and right gonads from both female and male embryos at the 7 th to the 14 th days of incubation. Transcripts for the first three enzymes (P-450 scc, 3 $\beta$-HSD and P-450c17), which convert cholesterol to androstenedione, were detected in the left and right gonads of both female and male embryos at as early as the 7 th day of incubation. The same patterns of expression of these three genes continued until the 14th day of incubation (Fig. 2). In contrast, transcripts for the remaining two enzymes, $17 \beta-$ HSD and aromatase, which convert androstenedione to estradiol-17 $\beta$, were detected in both left and right gonads only in the female embryo at the 7 th day of incubation. The female-specific expression of these two genes continued to the 14th day of incubation (Fig. 2). Although asymmetric development of the left and right gonads in females is clearly shown by the 14th day of incubation (Fig. 2), it is notable that transcripts of genes for all the five enzymes to produce estradiol-17 $\beta$ were also present in the regressing right gonad.

The sex-dependent differential transcription of genes for $17 \beta$-HSD and aromatase could also be demonstrated by RT-PCR. When total RNA samples from a mixture of the left and right gonads from an individual male or female embryo at the 7 th, 10th or 14th day of incubation were subjected to RT-PCR, the amplified cDNA sequences for $17 \beta$-HSD and aromatase were only detected for the RNA samples from the gonads of female embryos after 25 cycles of PCR (Fig. 3). When 40 cycles of PCR were applied, amplified cDNA sequences became detectable for the RNA samples from the male embryos also. However, the levels of amplification of aromatase cDNA for the samples from the male were still significantly lower than those obtained after 25 cycles of PCR for the samples from the female. These results indicate that concentrations of transcripts for these two enzymes, particularly for aromatase, are considerably lower in the male gonads than in the female gonads.

For the female gonad-specific expression of the $17 \beta$-HSD gene, it must be borne in mind that the antisense RNA probe was transcribed from the cDNA template cloned from the chicken ovary, and thus, the possibility remains that male embryonic gonads may contain a different molecular species of $17 \beta$-HSD mRNA that is undetectable with the present probe, as in the case of mammalian tissues (Labrie et al. 1997). However, even taking this possibility into account, the results shown in Figs 2 and 3 , taken together, indicate that conditions for the synthesis of estradiol-17 $\beta$ from cholesterol are established at the transcriptional level in both left and right gonads of female embryos, but that such synthesis should not occur at a significant level in the left and right gonads of male embryos because of the virtual absence of aromatase mRNA.

\section{Differential expression of estrogen receptor gene}

The presence of transcripts from the estrogen receptor gene was examined by in situ hybridization as above. A low but unequivocal level of estrogen receptor transcripts was detected in the epithelium, and later also in the cortex, of the left gonad, but not in the right gonad, of female embryos at the 7 th to 14th days of incubation (Fig. 4). Interestingly, signals indicating the presence of estrogen receptor transcripts were also detectable in the epithelium of the left gonad of male embryos at the 7 th to 12 th days of incubation. No signal was observed for the right gonad of male embryos (Fig. 4). However, the presence of estrogen receptor transcripts in the left gonad of male embryos was transient. The region showing the signal and its intensity became smaller and fainter at the 10th to 12 th days of incubation (arrows in Fig. 4) and the signal was no longer detectable by in situ hybridization at the 14th day of incubation.

Levels of estrogen receptor transcripts were also examined by RT-PCR. Because amplification of the estrogen receptor $\mathrm{CDNA}$ sequence was undetectable by 35 cycles of PCR for the total cDNA samples from the left gonad of both male and female embryos at the 8 th day of incubation, 40 cycles of PCR were applied to all the total cDNA samples from individual embryonic gonads. As illustrated in Fig. 5 and summarized in Table 1, the amplified cDNA fragments were undetectable at the 5th day of incubation, but detectable in a small number of samples from the left gonad of both sexes at the 6th day of incubation, and detectable for all samples from the left gonad of both sexes at the 7 th to 10 th days of incubation. The RT-PCR products were no longer detectable for the majority of RNA samples from the left gonad of the male at the 14th day of incubation, were present in even fewer when incubation was continued to the 18 th day, and became totally undetectable at the $3 \mathrm{rd}$ day after hatching. The RT-PCR products were undetectable in all samples from the right gonad of both sexes during the incubation period examined.

The results of both in situ hybridization and RT-PCR imply that transcription of the estrogen receptor gene takes place only in the left gonad 


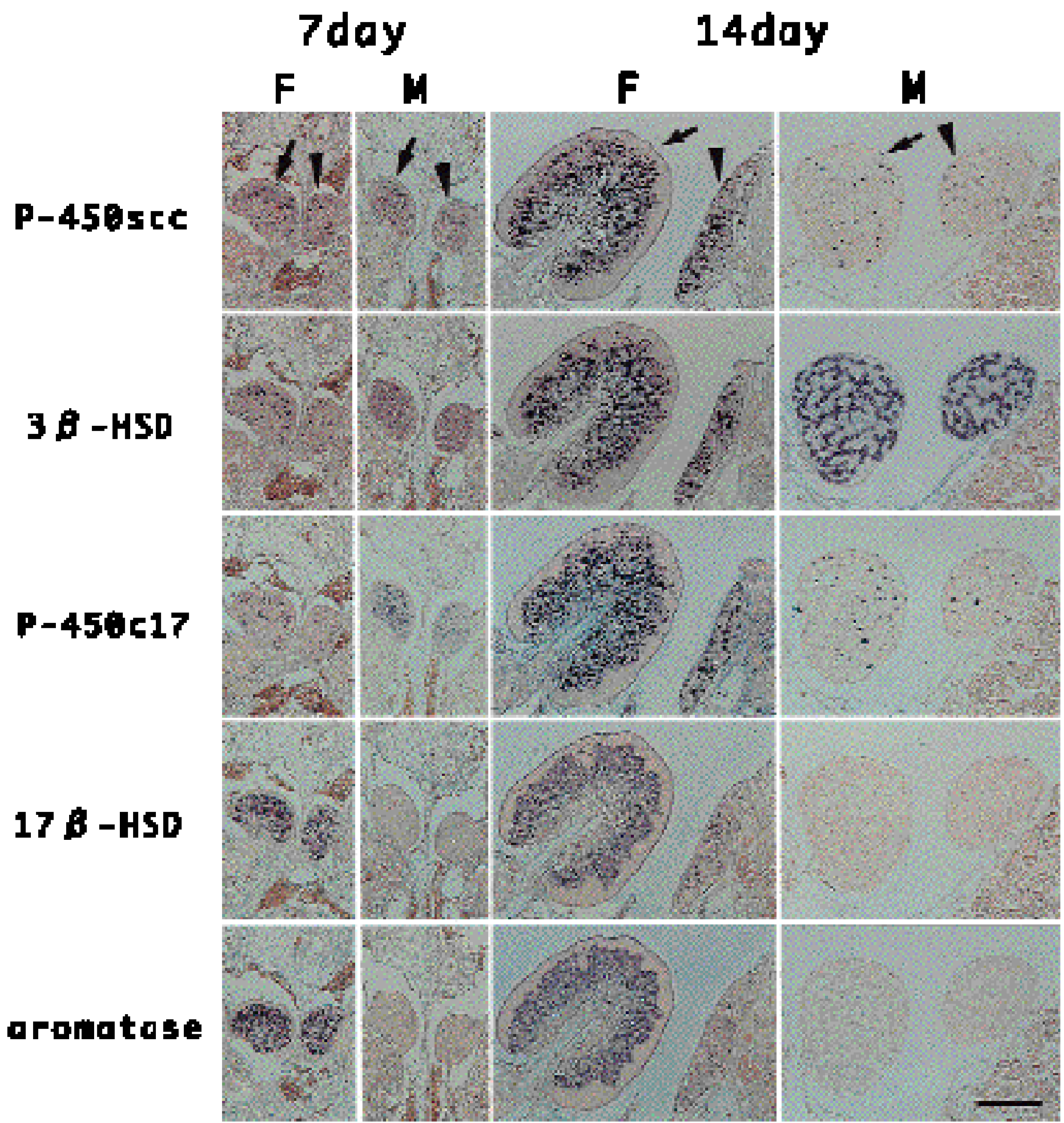

FIGURE 2. Detection of RNA transcripts from the five genes required for the conversion of cholesterol to estradiol-17 $\beta$ in the embryonic gonads of chicken. Results of $i n$ situ hybridization with DIG-labeled antisense RNA probes for the transcripts, as indicated, to tissue sections containing left (arrow) and right (arrowhead) gonads of the female (F) or male (M) embryos at the 7 th or 14th day of incubation. Hybrids were detected by the reaction with alkaline phosphatase-conjugated anti-DIG antibody. Reactions with the sense RNA probes did not produce signals (not shown). Bar represents $300 \mu \mathrm{m}$.

of both female and male embryos. The level of estrogen receptor transcripts in the male left gonad was comparable to that in the female at the 7 th day of incubation, but decreased rapidly thereafter.

\section{Effect of in ovo treatment with estrogen}

In order to investigate if a potentially functional estrogen receptor is produced in the left gonad of an early male embryo, and if the absence of expression 


\section{$\frac{7}{F \quad M} \frac{10}{F M} \frac{14(\text { day) }}{F \quad M}$}

cycles $25 \quad 25 \quad 40 \quad 252540 \quad 25 \quad 2540$

$17 \beta-H S D$

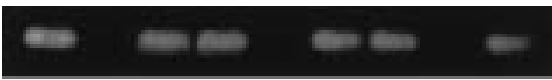

aromatase

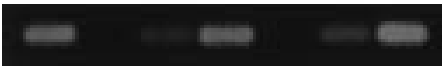

FIGURE 3. Detection of RNA transcripts from $17 \beta$-HSD and aromatase genes in the gonads of an individual embryo by RT-PCR. Ethidium

bromide-stained RT-PCR products $(152 \mathrm{bp}$ for the $17 \beta$-HSD mRNA and $135 \mathrm{bp}$ for the aromatase mRNA) after 25 or 40 cycles of PCR for the total RNA samples from the left plus right gonads of an individual female (F) or male (M) embryo at the 7 th, 10 th or 14 th day of incubation.

of the estrogen receptor gene in the right gonad is caused by a downregulation as a result of the virtual absence of estrogen synthesis from within the tissue in female embryos, embryos were administered in ovo with estradiol-17 $\beta$ from the 5 th to the 14 th day of incubation. As has long been known (Romanoff 1960), this treatment caused development of a left ovotestis, with a conspicuous cortex, in the male embryo (Fig. 6). In situ hybridization with the antisense RNA probe for aromatase mRNA demonstrated that aromatase gene transcripts were present at a low level in the medulla of the left gonad and also in the right gonad of the treated male embryo
(Fig. 6). In situ hybridization with the antisense RNA probe for estrogen receptor mRNA demonstrated that estrogen receptor gene transcripts were present in the cortex of the developing left ovotestis in the treated male embryo to an extent comparable to that in the left gonad of the treated female embryo (Fig. 6), whereas these transcripts were undetectable in the right gonad of both the treated female and the treated male embryos (Fig. 6). Absence of transcripts of the estrogen receptor gene in the estrogen-treated right gonad in both sexes was also demonstrated by RT-PCR (Fig. 5, Table 1). These results strongly suggest that a potentially active estrogen receptor, which can respond to the administered estrogen, is produced in the left gonad of an early male embryo, and that the absence of estrogen receptor gene expression in the right gonad in both sexes is an intrinsic character and is not caused by downregulation.

\section{DISCUSSION}

The results obtained in this study at the transcriptional level serve well to explain the known features of gonadal development in chickens (Fig. 7). Formation of germinal epithelium is noticeable in the left gonad, but not in the right gonad, of both sexes by the 6th day of incubation (data not shown). At the transcriptional level, all the genes required for the conversion of cholesterol to estradiol-17 $\beta$ are

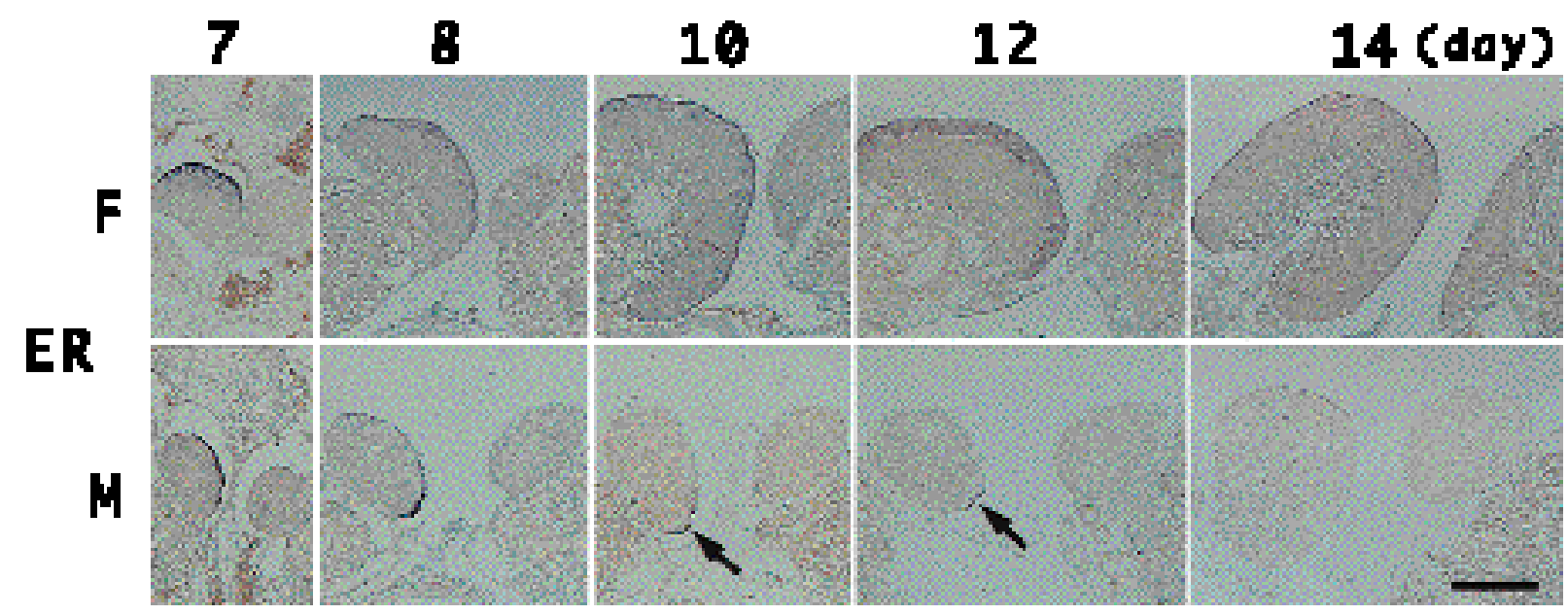

FIGURE 4. Detection of RNA transcripts from the estrogen receptor (ER) gene in embryonic gonads of chicken by in situ hybridization with the antisense RNA probe. The DIG-labeled antisense RNA probe, synthesized from the estrogen receptor cDNA template, was hybridized to a tissue section containing left and right gonads of a female (F) or male (M) embryo at the 7 th, 8 th, 10th, 12th or 14th day of incubation. Detection of hybrids was carried out as in Fig. 2 with some modifications as described in Materials and Methods. The localized and marginal presence of estrogen receptor transcripts is shown by an arrow. Bar represents $300 \mu \mathrm{m}$. 


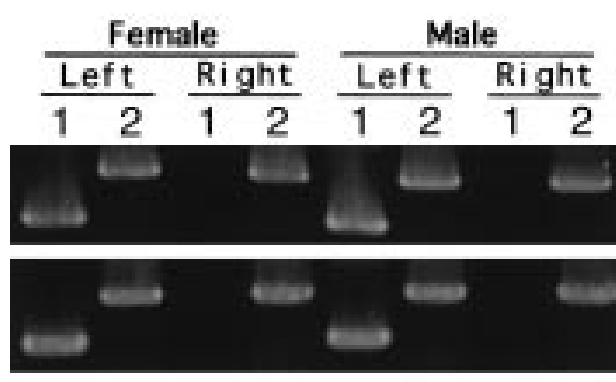

(day)

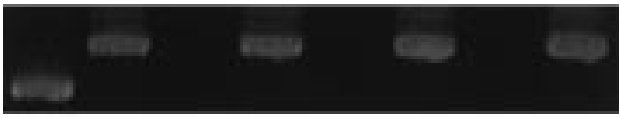

14

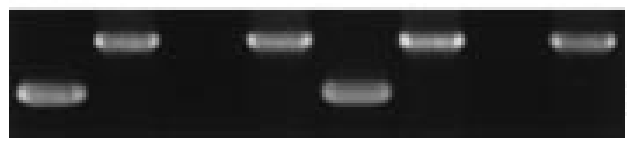

\section{4}

(treated)

FIGURE 5. The left-gonad-specific expression of the estrogen receptor (ER) gene as demonstrated by RT-PCR. The total RNA sample from a left or right gonad of an individual chicken embryo at the day of incubation as indicated was subjected to RT-PCR (40 cycles) using primers to detect RNA transcripts from the estrogen receptor gene (lane 1) or the GAPDH gene (lane 2). Sizes of the ethidium bromide-stained amplified products are given in Table 1. Panel ' 14 (treated)': estradiol-17 $\beta$ was added in ovo from the 5 th to the 14 th day of incubation.

expressed during the 7 th to 14 th days of incubation in both left and right gonads of the female. This suggests that, unless an aromatase inhibitor is

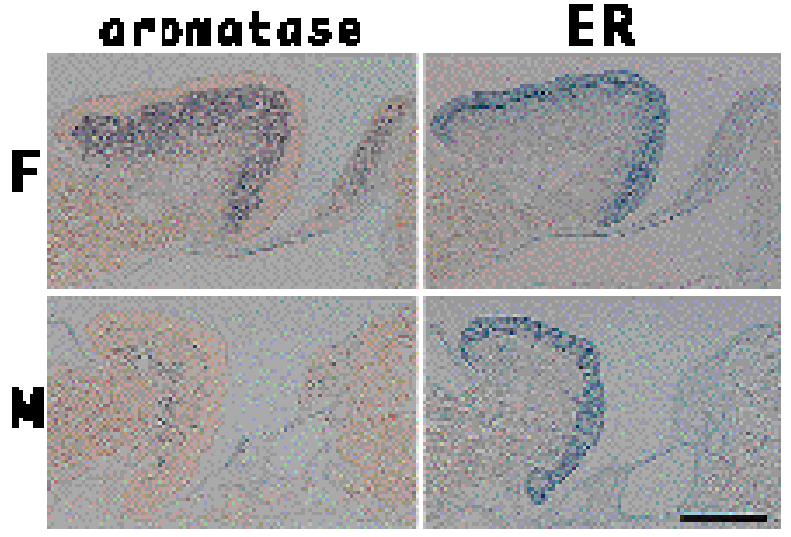

FIGURE 6. Effect of in ovo treatment with estradiol-17 $\beta$ on the expression of the aromatase and estrogen receptor (ER) genes in embryonic gonads. Both female $(\mathrm{F})$ and male (M) embryos were treated with estradiol-17 $\beta$ from the 5 th to the 14 th day of incubation. Detection of RNA transcripts by in situ hybridization was carried out as in Fig. 2. Note the development of a left ovotestis with a conspicuous cortex in the treated male embryo.

administered, estrogen is produced in those female gonads. The estrogen produced causes development of the ovarian cortex in the female left gonad, because the estrogen receptor gene is expressed in the epithelium of only the left gonad in a female embryo. In the female right gonad, cortex is not developed because of the intrinsic absence of estrogen receptor gene expression, and the tissue

TABLE 1. Detection of RNA transcripts from the estrogen receptor gene by RT-PCR in the left or right gonad from an individual female or male chicken embryo and from a newly hatched male chicken

\begin{tabular}{|c|c|c|c|c|}
\hline & \multicolumn{2}{|c|}{ Female } & \multicolumn{2}{|l|}{ Male } \\
\hline & Left & Right & Left & Right \\
\hline \multicolumn{5}{|l|}{$\begin{array}{l}\text { Days of } \\
\text { incubation }\end{array}$} \\
\hline 5 & $0 / 20$ & $0 / 20$ & $0 / 20$ & $0 / 20$ \\
\hline 6 & $3 / 20$ & $0 / 20$ & $2 / 20$ & $0 / 20$ \\
\hline 7 & $5 / 5$ & $0 / 5$ & $5 / 5$ & $0 / 5$ \\
\hline 8 & $5 / 5$ & $0 / 5$ & $5 / 5$ & $0 / 5$ \\
\hline 10 & $5 / 5$ & $0 / 5$ & $5 / 5$ & $0 / 5$ \\
\hline 12 & $5 / 5$ & $0 / 5$ & $16 / 20$ & $0 / 20$ \\
\hline 14 & $5 / 5$ & $0 / 5$ & $6 / 20$ & $0 / 20$ \\
\hline \multicolumn{5}{|l|}{14} \\
\hline (treated) & $25 / 25$ & $0 / 25$ & $23 / 23$ & $0 / 23$ \\
\hline 18 & NT & NT & $2 / 20$ & $0 / 20$ \\
\hline 3 days after hatching & NT & NT & $0 / 20$ & $0 / 20$ \\
\hline
\end{tabular}

Values are numbers of samples for which the amplified estrogen receptor cDNA fragments of $677 \mathrm{bp}$ were detected after 40 cycles of PCR/numbers of individual gonads tested. As a control, RT-PCR for the GAPDH mRNA was carried out, and amplification of a $1.03 \mathrm{~kb}$ cDNA fragment was detected for all the RNA samples tested (data not shown). 14 (treated), estradiol-17 $\beta$ was added in ovo from the 5 th to the 14 th day of incubation. NT, not tested. 


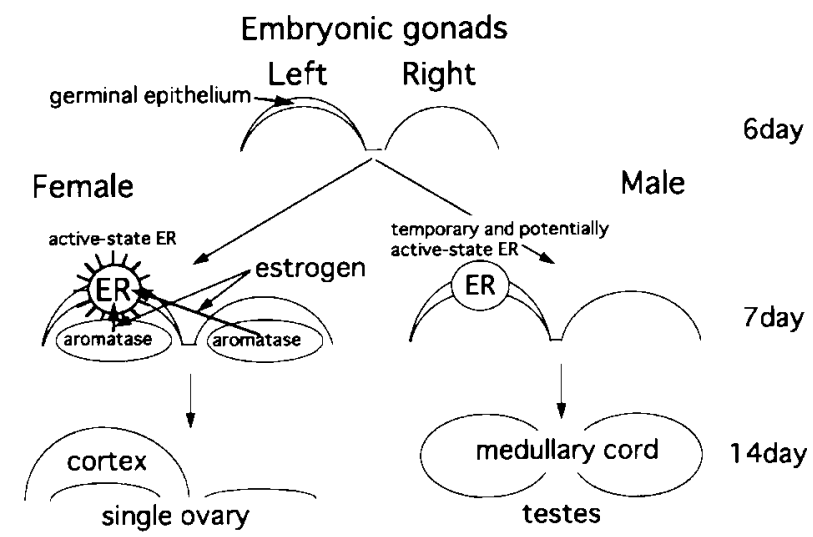

FIGURE 7. Model explaining the sex-specific features in the development of gonads in chicken embryos.

Differential expression of the genes for aromatase and estrogen receptor (ER), as demonstrated in this study, serves well to explain the specific development of cortex responding to estradiol-17 $\beta$ in the female left gonad, but not in the female right gonad, or in the male left or right gonads. The ability of the male left gonad to be morphologically sex-reversed, upon administration of estradiol-17 $\beta$ to an embryo at an early stage, can also be explained by the transient expression of the estrogen receptor gene.

regresses without receiving this hormonal stimulation. In contrast, although the estrogen receptor gene is expressed transiently in the epithelium of the male left gonad, estrogen should not be produced because of the virtual absence of expression of the aromatase gene that is required for the synthesis of either estrone or estradiol-17 $\beta$. Thus the cortex is not developed in both left and right gonads of a male embryo. Instead, medullary cords are developed in both left and right gonads in a male embryo, in response to androstenedione production or to testosterone, which may be produced if an, as yet unknown, $17 \beta$-HSD gene is expressed in early male gonads. The biological significance of the transient expression of the estrogen receptor gene in the epithelium of the male left gonad in the absence of the production of estrogen is unknown, but it serves to explain the development of a left ovotestis when estrogen is administered to a male embryo at an early stage of development (Romanoff 1960). One puzzling observation was that aromatase gene transcripts were present at a low level in the estrogen-treated male right gonad (Fig. 6), in which the expression of the estrogen receptor gene was undetectable (Figs 5 and 6, Table 1). We speculate that a diffusible factor causing expression of the aromatase gene in the right gonad is produced from the left gonad that has responded to estrogen.
The present observation that transcripts for all the five genes required for the synthesis of estrogen are present in the regressing right gonad in female embryos is consistent with earlier studies in which small amounts of estrone and estradiol-17 $\beta$ were detected by radioimmunoassay in the cultured right gonad from female chicken or quail embryos (Guichard et al. 1977, 1979, Teng \& Teng 1977, Scheib et al. 1981) or by immunofluorescence staining of gonadal sections from female chicken embryos (Woods \& Erton 1978).

The virtual absence of aromatase gene transcripts in the gonads of male embryos is consistent with the observation by Imataka et al. (1989) that the production of radiolabeled estradiol-17 $\beta$ could be detected only in tissue slices of female chicken embryonic gonad incubated with a radiolabeled precursor steroid, but is inconsistent with the detection of small amounts of estrogen in male chicken embryonic gonads by radioimmunoassay or immunofluorescence staining (Guichard et al. 1977, 1979, Woods \& Erton 1978, Tanabe et al. 1986). The latter observations may be explained by the detection of small amounts of aromatase cDNA fragment in male embryonic gonads after 40 cycles of PCR (Fig. 3). Recently, Yoshida et al. (1996) compared expression of aromatase and $\mathrm{P}-450 \mathrm{c} 17$ genes in embryonic gonads of chicken using an experimental approach similar to that in the present study, and showed that the aromatase gene was expressed only in female gonads. However, our present study is the first to compare expression of all the five genes required for the synthesis of estradiol-17 $\beta$ during gonadal development in chicken embryos.

The intriguing observation in this study that the expression of the estrogen receptor gene took place in the epithelium of the left, but not of the right, gonad of both sexes, although the expression in the male was transient, complements the observation made by Gasc (1980) that $\left[{ }^{3} \mathrm{H}\right]$ estradiol intravenously injected into a 5.5-7-day chicken embryo was distributed in the epithelium of the left gonad of both sexes, as shown by autoradiography. However, our present results differ from the finding by Gasc in his same study that $\left[{ }^{3} \mathrm{H}\right]$-radioactivity was also present in the medulla of both left and right gonads of both sexes at the 6th, but not the 10th, day of incubation. In the present study, the earliest consistent detection of estrogen receptor gene expression by RT-PCR was made at the 7 th day of incubation and, at this stage, no sign of its expression was detected in the right gonad of both sexes, by either RT-PCR or in situ hybridization.

The present results emphasize that studies on regulatory mechanisms causing female-gonadspecific transcription of the aromatase gene and 
left-gonad-specific expression of the estrogen receptor gene are important for the understanding of molecular mechanisms of sex differentiation of birds. The former mechanism would give a clue to link differentiation of the female gonad to the function of a putative sex-determining gene on the $\mathrm{W}$ chromosome, and the latter mechanism may be related to an intriguing developmental problem of left-right differences in gene expression that have been reported recently for other genes (Levin et al. 1995, Meno et al. 1996).

At present, it is unknown if a homologue of the estrogen receptor- $\beta$ gene (Kuiper et al. 1996) is present in chickens. However, even were such a gene present in chickens, it seems unlikely that it is expressed to a significant level in the right gonad of a female embryo, because regression of the right gonad and the unilateral development of the ovary are so obvious.

\section{ACKNOWLEDGEMENTS}

This work was supported by a Grant-in-Aid for Scientific Research on Priority Areas from the Ministry of Education, Science, Sports and Culture, Japan and by the Mitsubishi Foundation.

\section{REFERENCES}

Dugaiczyk A, Haron JA, Stone EM, Dennison OE, Rothblum KN \& Schwarts RJ 1983 Cloning and sequencing of a deoxyribonucleic acid copy of glyceraldehyde-3-phosphate dehydrogenase messenger ribonucleic acid isolated from chicken muscle. Biochemistry 22 1605-1613.

Elbrecht A \& Smith RG 1992 Aromatase enzyme activity and sex determination in chickens. Science 255 467-470.

Gasc J-M 1980 Estrogen target cells in gonads of the chicken embryo during sexual differentiation. Fournal of Embryology and Experimental Morphology 55 331-342.

Guichard A, Cedard L, Mignot T-M, Scheib D \& Haffen K 1977 Radioimmunoassay of steroids produced by cultured chick embryonic gonads: differences according to age, sex, and side. General and Comparative Endocrinology 32 255-265.

Guichard A, Cedard L, Mignot T-M, Scheib D \& Haffen K 1979 Radioimmunoassay of steroids produced by chick embryo gonads cultured in the presence of some exogenous steroid precursors. General and Comparative Endocrinology 39 9-19.

Imataka H, Suzuki K, Inano H, Kohmoto K \& Tamaoki B 1989 Biosynthetic pathways of testosterone and estradiol-17 $\beta$ in slices of the embryonic ovary and testis of the chicken (Gallus domesticus). General and Comparative Endocrinology 73 69-79.

Kodama H, Saitoh H, Tone M, Kuhara S, Sakaki Y \& Mizuno S 1987 Nucleotide sequences and unusual electrophoretic behavior of the $\mathrm{W}$ chromosome-specific repeating DNA units of the domestic fowl, Gallus gallus domesticus. Chromosoma 96 $18-25$.
Koopman P, Gubbay J, Vivian N, Goodfellow P \& Lovell-Badge R 1991 Male development of chromosomally female mice transgenic for Sry. Nature 351 117-121.

Krust A, Green S, Argos P, Kumar V, Walter P, Bornert JM \& Chambon P 1986 The chicken oestrogen receptor sequence: homology with v-erb $A$ and the human oestrogen and glucocorticoid receptors. EMBO fournal 5 891-897.

Kuiper GGM, Enmark E, Pelto-Huikko M, Nilsson S \& Gustafsson JA 1996 Cloning of a novel estrogen receptor expressed in rat prostate and ovary. Proceedings of the National Academy of Sciences of the USA 93 5925-5930.

Labrie F, Luu-The V, Lin SX, Labrie C, Simard J, Breton R \& Belanger A 1997 The key role of $17 \beta$-hydroxysteroid dehydrogenases in sex steroid biology. Steroids 62 148-158.

Levin M, Johnson RL, Stern CD, Kuehn M \& Tabin C 1995 A molecular pathway determining left-right asymmetry in chick embryogenesis. Cell 82 803-814.

Lin M, Thorne MH, Martin ICA, Sheldon BL \& Jones RC 1995 Development of the gonads in the triploid (ZZW and ZZZ) fowl, Gallus domesticus, and comparison with normal diploid males $(\mathrm{ZZ})$ and females $(\mathrm{ZW})$. Reproduction, Fertility and Development 7 1185-1197.

Lizardi PM \& Engelberg A 1979 Rapid isolation of RNA using proteinase $\mathrm{K}$ and sodium perchlorate. Analytical Biochemistry 98 116-122.

McPhaul MJ, Noble JF, Simpson ER, Mendelson CR \& Wilson JD 1988 The expression of a functional cDNA encoding the chicken cytochrome P-450 arom (aromatase) that catalyzes the formation of estrogen from androgen. Fournal of Biological Chemistry 263 16358-16363.

Meno C, Saijoh Y, Fujii H, Ikeda M, Yokoyama T, Yokoyama M, Toyoda Y \& Hamada H 1996 Left-right asymmetric expression of the TGF $\beta$-family member lefty in mouse embryos. Nature 381 151-155.

Mizuno S, Saitoh Y, Nomura O, Kunita R, Ohtomo K, Nishimori K, Ono H \& Saitoh H 1993 Sex-specific DNA sequences in Galliformes and their application to the study of sex differentiation. In Manipulation of the Avian Genome, pp 257-274. Eds RJ Etches \& AMV Gibbins. Boca Raton: CRC Press Inc.

Nakabayashi O, Nomura O, Nishimori K \& Mizuno S 1995 The cDNA cloning and transient expression of a chicken gene encoding a $3 \beta$-hydroxysteroid dehydrogenase $/ \Delta^{5-4}$ isomerase unique to major steroidogenic tissues. Gene 162 261-265.

Nomura O, Nakabayashi O, Nishimori K \& Mizuno S 1997 The cDNA cloning and transient expression of a chicken gene encoding cytochrome P-450 scc. Gene 185 217-222.

Ohno S, Kittrell WA, Christian LC, Stenirs C \& Witt GA 1963 An adult triploid chicken (Gallus domesticus) with a left ovotestis. Cytogenetics 2 42-49.

Ono H, Iwasaki M, Sakamoto N \& Mizuno S 1988 cDNA cloning and sequence analysis of a chicken gene expressed during the gonadal development and homologous to mammalian cytochrome P-450c17. Gene 66 77-85.

Romanoff AL 1960 The Avian Embryo: Structural and Functional Development, pp 816-853. New York: Macmillan Ltd.

Sambrook J, Fritsch EF \& Maniatis T 1989 Extraction of RNA with guanidinium thiocyanate followed by centrifugation in cesium chloride solutions. In Molecular Cloning. A Laboratory Manual, edn 2, 7·19-7·22. Cold Spring Harbor: Cold Spring Harbor Laboratory Press.

Scheib D, Guichard A, Mignot T-M \& Cedard L 1981 Steroidogenesis by gonads of normal and of diethylstilbestrol-treated quail embryos: radioimmunoassays on organ cultures. General and Comparative Endocrinology 43 $519-526$.

Fournal of Molecular Endocrinology (1998) 20, 193-202 
Tanabe Y, Saito N \& Nakamura T 1986 Ontogenic steroidogenesis by testes, ovary, and adrenals of embryonic and postembryonic chickens (Gallus domesticus). General and Comparative Endocrinology 63 456-463.

Teng CT \& Teng CS 1977 Studies on sex-organ development: the hormonal regulation of steroidogenesis and adenosine $3^{\prime}: 5^{\prime}$-cyclic monophosphate in embryonic-chick ovary. Biochemical Fournal 162 123-134.

Wajima S, Kawauchi S, Furusawa T, Wakabayashi N, Nakabayashi O, Nishimori K \& Mizuno S 1995 The cDNA cloning and analysis of expression of chicken $17 \beta$-hydroxysteroid dehydrogenase. Proceedings of the 68th
Annual Meeting of the Japanese Biochemical Society, Sendai, 7 September 1995, Abstract No. 3828. Seikagaku (in Japanese) 67, 899.

Woods JE \& Erton LH 1978 The synthesis of estrogen in the gonads of the chick embryo. General and Comparative Endocrinology 36 360-370.

Yoshida K, Shimada K \& Saito N 1996 Expression of $\mathrm{P} 450_{17 \alpha}$ hydroxylase and P450 aromatase genes in the chicken gonad before and after sexual differentiation. General and Comparative Endocrinology 102 233-240.

RECEIVED 30 June 1997 